\title{
Sovereignty between the Katechon and the Eschaton: Rethinking the
}

\author{
Leviathan
}

\begin{abstract}
This paper both rejects the reading of Hobbes's Leviathan as a secularised katechon and rethinks anew the questions of sovereignty and politics in his thought. It does so by examining the eschatological character of his politico-theological understanding of the relation between the kingdom of the Leviathan and the kingdom of God. Indeed, through different contemporary readings of Hobbes's theory of the State, this paper offers an insight into the concrete eschatology at operation in Hobbes's thought and underscores its relevance for the understanding of government, biopolitics and sovereignty. This is achieved through two different, albeit interconnected undertakings, which in turn allow us to agree but also to go beyond Agamben's claim that the State, in Hobbes, does not have a katechontic function. The first is an exposition of the a-teleological character of Hobbes's eschatology and his metaphysics of motion. The second involves a consideration of the temporality and the nature of the relation between the a-historical world of reason and the historical world of faith that underpins Hobbes's theory of the State. Contrary to the contemporary interpretations in which Hobbes's eschatology is presented as future regarding, we will highlight the chronological coincidence between the historical time of faith and the a-historical time of the Leviathan, placing Hobbes within the political coordinates of Benjamin's messianism. By bringing this eschatological perspective to the fore, not only will the reading of Hobbes's theory of sovereignty that aligns him with liberalism be problematized, but also, an analysis of the resources that Hobbes offers to imagine a different form of politics will be developed.
\end{abstract}

\section{Introduction}

This paper both rejects the reading of Hobbes's Leviathan as a secularised katechon and rethinks anew the questions of sovereignty and politics in his thought. It does so by examining the eschatological character of his politico-theological understanding of the relation between the kingdom of the Leviathan and the kingdom of God. Indeed, through different contemporary readings of Hobbes's theory of the State, ${ }^{1}$ this paper offers an insight into the concrete eschatology at operation in Hobbes's thought and underscores its relevance for the understanding of government, biopolitics and sovereignty. This is achieved through two different, albeit interconnected

\footnotetext{
1 In particular we will draw from Pocock's study of Hobbes's eschatology in John G.A. Pocock, Politics, Language and Time: Essays on Political Thought and History (London: Methuen, 1972); from James Martel, Subverting the Leviathan: Reading Thomas Hobbes as a Radical Democrat (New York: Columbia University Press, 2007); and from Giorgio Agamben, Stasis: Civil War as a Political Paradigm, Trans. Nicholas Heron (Edinburgh: Edinburgh University Press, 2015).
} 
undertakings, which in turn allow us to agree but also to go beyond Agamben's claim that the State, in Hobbes, does not have a katechontic function. ${ }^{2}$ The first is an exposition of the a-teleological character of Hobbes's eschatology and his metaphysics of motion. The second involves a consideration of the temporality and the nature of the relation between the a-historical world of reason and the historical world of faith that underpins Hobbes's theory of the State.

By bringing this eschatological perspective to the fore, not only will the reading of Hobbes's theory of sovereignty that aligns him with liberalism be problematized, but also, an analysis of the resources that Hobbes offers to imagine a different form of politics will be developed. Indeed, contrary to the contemporary interpretations in which Hobbes's eschatology is presented as future regarding, we will highlight the chronological coincidence between the historical time of faith and the a-historical time of the Leviathan, placing Hobbes within the political coordinates of Benjamin's messianism. Before developing this interpretation of Hobbes's theory of the State, a brief account of the katenchontic reading of his theory of sovereignty will be presented in the opening section, followed by a critique of this reading and an examination of both the particularity of Hobbes's eschatology and the understanding of motion that grounds his theory of the state.

\section{The Leviathan as a secularized Katechon}

The notion of the katechon, which in Greek translates as "the one who withholds" -

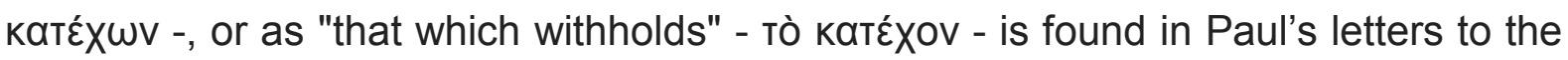
Thessalonians in an eschatological context: in explaining why the second coming of Christ had been delayed, Paul asserts that until the man of lawlessness "seats himself in the sanctuary of God and declares himself to be God"3 there will not be a second coming. "You know what it is that is now holding him back, so that he will be revealed when the time comes. For the mystery of anomy is already at work, but only until the person now holding him back (ho katechon) is removed. Then the lawless

\footnotetext{
2 Agamben, Stasis, p. 53.

${ }^{3} 2$ Thessalonians 2:3-9 (Revised Standard Version).
} 
one (anomos) will be revealed, whom the Lord will abolish with the breath of his mouth, rendering him inoperative by the manifestation of his presence (parousia)." At first glance, the katechon appears as an "ambiguous figure who both holds back the already operative 'mystery of lawlessness' and, by extending secular history, delays the final redemption". ${ }^{5}$ Yet, as Agamben suggests, if the identification of the man of lawlessness with the Antichrist is commonly accepted, the question that remains open is that of the identification, character and nature of the katechon. ${ }^{6}$

A tradition inaugurated with Tertullian who associated the katechon with the Roman Empire and that reaches a climax with Schmitt's Political Theology, has given a positive historical function to the katechon as a power that delays or holds back the end of time. It is indeed with Schmitt, who this passage from the Thessalonians is read as grounding a Christian doctrine of State Power, that the katechon assumes a positive purpose more clearly, . There is, Schmitt argues, "in every century a concrete bearer of this force and that it is a matter of finding it [...] This is a total presence hidden under the veils of history." " Although its essence is not to be eternal, for Schmitt, the katechon is capable of being a historical power that stabilizes, as it were, the terrain of profane politics by restraining the coming of the antichrist.

Nevertheless, by remaining confined within Schmitt's understanding of order, this interpretation of the katechon - as that which "restrains the appearance of the Antichrist and the end of the present eon" ${ }^{8}$ - is unable to grasp the ambivalent character of the katechon. "Despite its obscurity" Agamben suggests, Paul "does not harbor any positive valuation of katechon. To the contrary, it is what must be held back in order that the "mystery of anomia"'9 be fully revealed. By protecting the people from the antichrist, the katechon defers the second coming, the final battle

\footnotetext{
${ }^{4} 2$ Thess, 2: 3-9.

5 Jessica Whyte, Catastrophe and Redemption: The Political Thought of Giorgio Agamben (New York: SUNY Press, 2013), p. 7.

6 Cfr. Giorgio Agamben, The Time that Remains, trans. Patricia Dailey (Stanford University Press, 2005).

7 Carl Schmitt, The Nomos of the Earth in the International Law of the Jus Publicum Europeaum, trans. G.L. Umen (New York: Telos, 2003), pp. 59-60.

8 Ibid., p 59.

9 Agamben, Time, p. 110.
} 
and hence the victory of Christ. ${ }^{10}$ This is precisely what Roberto Esposito indicates when claiming that the katechon has an aporetic character which lies in the fact that "by holding back evil, [it] also prevents the ultimate good from manifesting itself."11

Therefore, by thinking the function of the katechon only from the perspective of the deferral of the Antichrist, Schmitt entrenches himself in a conservative position that, while achieving its intention of bringing to the fore a Christian theory of the state, ends up eliminating concrete eschatology and hence salvation from the theologicopolitical horizon of profane politics:

This Christian empire was not eternal. It always had its own end and that of the present eon in view. Nevertheless, it was capable of being a historical power. The decisive historical concept of this continuity was that of restrainer: katechon. "Empire" in this sense meant the historical power to restrain the appearance of the Antichrist and the end of the present eon; it was a power that withholds... The empire of the Christian Middle Ages lasted only as long as the idea of the katechon was alive. ${ }^{12}$

This deferral of the eschaton, this delaying of the advent of the end, takes in Schmitt the concrete form of the Christian Empire: "the belief that a restrainer holds back the end of the world provides the only bridge between the notion of an eschatological paralysis of all human events and a tremendous historical monolith like that of the Christian Empire of the Germanic Kings."13 Therefore, for Schmitt, the present of humanity, as Agamben suggests, is "an interim founded on the delay of the

\footnotetext{
10 For Agamben, "it is therefore possible to conceive the Katechon and anomos not as two separate figures (unlike John, Paul never mentions and antichristos), but as one single power before and after the final unveiling. Profane power - albeit of the Roman Empire or any other power - is the semblance that covers up the substantial lawlessness [anomia] of messianic time. In solving the 'mystery,' semblance is cast out, and power assumes the figure of the anomos, of that which is the absolute outlaw [del fuorilegge assoluto]. This is how the messianic is fulfilled in the clash between the two parousiai: between that of the anomos, who is marked by the working of Satan in every power [potenza], and that of the Messiah, who will render energia inoperative in it". Agamben, Time, p. 111.

${ }^{11}$ Robeto Esposito, Two: The Machine of Political Theology and the Place of Thought, trans. Zakiya Hanafi (New York: Fordham University Press), p. 77.

12 Carl Schmitt, The Nomos of the Earth in the International Law of the Jus Publicum Europeaum, trans. G.L. Umen (New York: Telos, 2003), pp. 59-60.

13 Ibid., p. 60.
} 
Kingdom." ${ }^{14}$ In this particular sense, the katechon appears in Schmitt as that which produces history, or as Bredekamp has put it "the space of time between the present and the coming of the Antichrist." ${ }^{15}$ It is for this reason that, according to this interpretation, the katechon rules out concrete eschatology and in so doing produces the "neutralisation of a philosophy of history oriented toward salvation."16

It comes as no surprise that Hobbes's theory of the state has been taken as a secularization of this particular understanding of the katechon. It is in Hobbes that an understanding of the state as destined to block catastrophe and to delay the end of times comes to the fore in a paradigmatic manner: Leviathan holds back civil war, it keeps Behemoth in check, it imposes, at all costs, order over anomos. Hobbes's theory of state has been firmly placed within a tradition that concedes a positive valence to the katechon. For Prozorov, for instance, "the central figure in this secularization of the logic of the katechon is of course Thomas Hobbes, whose theory of sovereignty seeks precisely to ward off the anomic catastrophe of war of every man against every man, whose potentiality is inscribed in the state of nature." ${ }^{17}$ Needless to say, Prozorov is not alone in making this claim. In his study of the secularization of sacrificial christianity Wolfgang Palaver not only claims that "if we study Hobbes's political philosophy carefully, we will realize that his state functions like a katéchon: it provides for the permanent prevention of chaos and violence" 18 but also elevates the concept of the katechon as the organising principle of Hobbes's theory of the state.

However, this reading of Hobbes's theory of the state from the perspective of Schmitt's understanding of the katechon is not immediately justified and needs clarification. For Palaver there are "deep theological roots to Hobbes's katéchontic

14 Giorgio Agamben, The Kingdom and the Glory: For a Theological Genealogy of Economy and Government, trans. Lorenzo Chiesa (Stanford University Press, 2011), p. 7.

15 Horst Bredekamp, Melissa Thorson Hause and Jackson Bond "From Walter Benjamin to Carl Schmitt via Thomas Hobbes," Critical Inquiry 25 (1999): 252.

${ }^{16}$ Agamben, Kingdom, p. 7.

17 Sergei Prozorov, "The katechon in the age of biopolitical nihilism," Continental Philosophy Review 45, (2012): 487.

18 Wolfgang Palaver, "Hobbes and the Katechon: The Secularization of Sacrificial Christianity," Contagion: Journal of Violence, Mimesis and Culture 2 (1995): 63. 
solution to civil war"19 that he ultimately traces back to the resemblance of Leviathan with Hobbes's own image of God. Secularization, in this sense, takes the form of an analogy, a correspondence between sovereign power and God by which the former imitates the later. The secularization of the katechon in Hobbes represents then, for Palaver, the transfer of a theological concept to political philosophy. This reading of Hobbes's Leviathan is further justified with recourse to the historical developments produced with the advent of the Reformation:

The Reformation had put an end to Medieval Christianity. There was no longer a real successor of the Roman Empire. The Catholic Church was not able to function as an institution that could create order in Europe. Religion became instead a source of wars. Hobbes, therefore, had a secular institution that could at least locally secure peace and tranquillity. He proposed the secular state as a creator of peace. The differences between Hobbes's secular state and medieval Christianity can explain his break with the katechon-tradition of the Roman Empire [...]. Hobbes's state can, nevertheless, be called a katechon. As a secularised concept, transferred to the State, the concept of the katechon can be seen as a structuring principle of Hobbes's political philosophy. ${ }^{20}$

In The Time that Remains Agamben acknowledges without explicitly endorsing this possible interpretation of Hobbes that locates within the very logic of Leviathan a positive Katechontic function. "In a certain sense" writes Agamben, "every theory of the state, including Hobbes's - which thinks of it as a power destined to block or delay catastrophe - can be taken as a secularization of this interpretation of 2 Thessalonians 2". ${ }^{21}$ Whether Agamben is discarding or not this interpretation that places Hobbes's Leviathan within a Schmittian understanding of the katechon is not immediately clear. However, the degree of ambivalence left unresolved in the Time that Remains with regards to Hobbes's theory of the state finds an unequivocal response in Agamben's Stasis: in Hobbes, profane politics does not have, "with respect to the kingdom, any katechontic function". ${ }^{22}$ In the next section we will build upon this claim, arguing that a katechontic reading of Hobbes's Leviathan is only possible at the expense of the eschatology at work in his philosophical system. Reading Hobbes's theory of the state from an eschatological perspective, we argue,

\footnotetext{
19 lbid., p. 64.

20 lbid., p. 67.

21 Agamben, Time, p. 110.

22 Agamben, Stasis, p. 53.
} 
allows us to revisit his conception of the sovereignty and to rethink anew the nature of the relation between the state, security and happiness, or to put it differently, the biopolitical undertone of his philosophical system.

\section{The concrete eschatology in Hobbes's thought}

Widely regarded as the pre-eminent thinker of the State tout court, one would be forgiven in thinking that for Hobbes the state constitutes the telos of human action, the terminus ad quem of individual human life that begins in the infamous state of nature. What we seek to do in this section, however, is to displace this account by reorienting Hobbesian concepts around the question of time, and in particular the question of eschatology. Following on from G.J.A Pocock, whose recovery of the theological aspects of Hobbes's thought is crucial, we seek to develop an account of sovereignty and the state that places the temporal dynamic at the centre of analysis by recovering the theologico-eschatological aspects of his thought.

As Derrida has noted many Hobbes scholars have identified Hobbes as developing a distinctly modern conception of sovereignty, one that is "emancipated from theology and religion". ${ }^{23}$ Yet, and we are in agreement with Derrida on this point, things are not quite so simple, and a reading which stresses the secular nature of Hobbes's work does more to obscure than to enlighten. Indeed, the theological aspects of Hobbes's work are crucial in order to understanding his conception of sovereignty. While Derrida sees in Hobbes a profound and fundamental theological and religious basis for his conception of state, this is presented in terms of the way sovereignty is an imitation of God on earth. For Derrida the human sovereign is "standing in for the absolute sovereign God." 24 What Derrida's reading misses, however, is the concrete eschatological aspect of Hobbes's work. Indeed, it is not only the case that Hobbes's philosophical system is underpinned by theology, but also, and perhaps more crucially, the theological aspect has a concrete eschatological character.

\footnotetext{
23 Jacques Derrida The Beast and the Sovereign, Volume 1, trans. Geoffrey Bennington (University of Chicago Press, 2009), p. 53.

24 Ibid.
} 
To place eschatology in Hobbes's thought in its proper locus, that is, as concrete eschatology, we can begin to unravel any simplistic notion of the Hobbesian state that presents it as that which holds back any and all disorder. G.J.A Pocock has provided the groundwork for an examination of the eschatological aspects of Hobbes's work ultimately identifying that there are two distinct realms operating in his philosophical system. One is that of "nature known to us through our philosophic reasoning on the consequences of our affirmations, the other of divine activity known to us through prophecy, the revealed and transmitted words of God". ${ }^{25}$ It is not the case that Hobbes's thought is secularised in any meaningful sense, but rather he conceives of two distinct contexts: an "a-historical world of reason" which is the location of the Leviathan and a "historical world of faith" which is to say the world of prophecy and scripture and which culminates in the kingdom of God. ${ }^{26}$ Indeed, Hobbes is emphatic here and decries the abuses of scripture which mistakes this world, or this church as the kingdom of God. ${ }^{27}$ Considered in this light, the kingdom of God is therefore put into its eschatological context: the second coming of Christ will inaugurate the kingdom of God which marks the end of the profane kingdom of the Leviathan:

The Kingdom of God, which CHRIST was sent by God the Father to restore, does not begin until his second coming, in fact from the day of judgement when he is to come in majesty in the company of angels. ${ }^{28}$

Here it is made manifest that Hobbes did not conceive of the Leviathan as the endpoint of politics, and hence this goes directly against Schmitt's thesis that "the goal and terminus is security of the civil, stately condition". ${ }^{29}$ Rather, Hobbes unremittingly insists on the "literal nature of Christ's return, the literal, physical and political character of his kingdom after the resurrection of the saints". ${ }^{30}$ The kingdom of God is not, for Hobbes a metaphorical kingdom, but constitutes a "kingdom properly so

\footnotetext{
${ }^{25}$ Pocock, Time, History and Eschatology, p. 159.

26 Ibid., p. 166.

27 Thomas Hobbes, Leviathan (Hertfordshire: Wordsworth Classics, 2014), p. 458.

${ }^{28}$ Thomas Hobbes, On the Citizen, ed. and trans. Richard Tuck (Cambridge University Press, 1998), pp. 206-207.

${ }_{29}$ Carl Schmitt, The Leviathan in the State Theory of Thomas Hobbes: Meaning and Failure of a Political Symbol, trans. George Schwab (London: Greenwood Press, 1996), p. 31.

${ }^{30}$ Pocock, Time, History and Eschatology, p. 173.
} 
named". ${ }^{31}$ That Hobbes conceives of the state not as an end-point but as that which must disappear with the second coming of Christ can be further explained with recourse to his metaphysics of motion, which underpins the concrete character of his eschatology.

In the Hobbesian universe ontological primacy is given to motion. In this way, Hobbes diverges from Aristotelean metaphysics which sees motion only as a thing striving towards its telos where it will come to finally rest: "[i]n that which has an end, a prior stage and the stages that follow are done for the sake of that end." 32 For Aristotle, the end is the goal and the terminus of the motion, hence he believed that the nature of a particular movement is determined by its intended destination. Therefore, in identifying a particular movement "the crucial consideration is the telos not the immediate or efficient cause". ${ }^{33}$ Things strive towards their fulfillment, and this is what moves them. There is then a concern in Aristotle with wholeness, completeness and stasis - the natural teleology that drives things toward their fulfillment - : "movement was expected to terminate itself by completing the actualization of that which was moved". ${ }^{34}$ In short, in the Aristotelian system, motion in and of itself becomes philosophically irrelevant as pre-eminence is given to destination and fulfilment.

On the other hand for Hobbes "organisms are characterized by natural tendencies, by inherent strivings; but this is the striving to persist, not the desire to reach a telos." 35 Perhaps nowhere else in Hobbes's writings does this partial rejection of Aristotelian metaphysics become so explicit as in his tract on Thomas White:

If we do allow the above interpretation [of Aristotle's definition] we may reasonably infer that that good genius which moves the earth has had either [i] a goal or objective towards which it moves the world or [ii] motivation towards, or a purpose in, the moving. We may not infer however that the world was endowed with motion with the express purpose that the motion so imparted, i.e. with the intention of [its

\footnotetext{
31 Hobbes, Leviathan, p. 309.

${ }^{32}$ Aristotle, Physics, trans. Hippocrates G. Apostle (Indiana University Press, 1969), p. 199a.

${ }^{33}$ Thomas Spragens, The Politics of Motion: The World of Thomas Hobbes (University of Kentucky Press, 1973), p. 57.

34 Ibid., p. 58.

35 lbid., p. 70
} 
reaching] an end, should at some time or other cease and be terminated. ${ }^{36}$

What we wish to emphasise here, however, is that it is this understanding of motion as having an infinite and a-teleological character, that undergirds Hobbes political philosophy. Indeed, Hobbes uses the state to illustrate the point that, while the material that constitutes a thing may change, this does not necessarily entail that it takes a different form, i.e. it can still be the same thing: "When any citizen dies, the material of the state is not the same, i.e. the state is not the same ens. Yet the uninterrupted degree [ordo] and motion of government that signalise a state ensure, while they remain as one, that the state is the same in number."37

There is a relation, as Hobbes reads Aristotle, between end and fulfillment. Once motion has reached its fulfillment, its telos, the motion then ceases. In this sense, motion is a temporary divergence from a natural state, which is rest. In Agamben's discussion of Paul, he raises the question, albeit briefly, as to whether telos means end or fulfillment. ${ }^{38}$ In Aristotle, end and fulfillment coincide. In Hobbes, however, things are not moved by their telos as in Aristotle. If motion is ontologically primary then the most important thing to consider is not the telos but the motion itself: "but the causes of universal things (of those, at least, that have any cause) are manifest of themselves, or (as they say commonly) known to nature; so that they need no method at all; for they have all but one universal cause, which is motion". 39 Thus, the idea of 'fulfillment' is completely anathema to the Hobbesian universe, in which motion has no other cause outside of motion. In this sense, the question that Agamben poses - whether telos means end or fulfillment - is rendered obsolete by Hobbes for whom there is no fulfillment, no rest, just "endless, aimless motion." 40 If, as we aim to argue here, this underpins Hobbes's philosophy of state then there is no tension between a potentiality of the state and its actuality, the state is not "striving" towards anything except its continued motion and existence. The state

${ }^{36}$ Thomas Hobbes, Thomas White's De Mundo Examined, trans. H.W. Jones (Bradford University Press, 1976), p. 493.

37 Ibid., p. 141.

${ }^{38}$ Agamben, Time, p. 98.

39 Thomas Hobbes, Human Nature \& De Corpore Politico (Oxford University Press, 1999) p. 197.

40 Spragens, Politics, p. 63. 
seen in this light cannot reach "fulfillment," it only persists, until the kingdom of God is once again restored. Thus there is no telos, no fulfillment - there is only an end.

Government is characterised by an infinite motion which ensures nothing more than the survival of the state itself. This, however, while true of the state, taken as an abstraction, is complicated by the other aspect of Hobbes's Leviathan - the historical dimension of faith. The evacuation of teleology does not entail an evacuation of eschatology. The movement of the state occurs, but not as a result of its end - which is the eschaton. The a-historical world of reason and state is autonomous with regard to the historical kingdom of God but eschatologically connected. Here, as Agamben notes, we find here a "curious affinity" 41 to Benjamin's Theologico-Political Fragment where we are presented with two distinct and autonomous realms, that of the messianic and that of the profane. While the messianic refers to the divine realm, the kingdom of God, the profane is the earthly historical condition in which we find ourselves. The kingdom of God, Benjamin writes, "is not the telos of the historical dynamic, it cannot be set as a goal. From the standpoint of history it is not the goal but the end". 42

Benjamin presents the relation of the kingdom of the profane and the kingdom of God as two arrows, pointed in opposite directions. The profane dynamic, though not a part of the kingdom of God, nevertheless operates to increase the intensity of the force of the opposite messianic arrow. The profane, he tells us, "although not a category of this Kingdom, is a decisive category of its quietest approach". 43 So, the implicit eschatological economy that is presented here by Benjamin is that of two kingdoms that are separate, autonomous, yet related in that the profane inadvertently intensifies the approach of the messianic event. The kingdom of God is the end of the profane kingdom. This particular conception of eschatology both coincides with and makes intelligible the relation that ties together sovereignty and the kingdom of God in Hobbes's thought.

\footnotetext{
${ }^{41}$ Agamben, Stasis, p. 52.

42 Walter Benjamin, Reflections: Essays, Aphorisms, Autobiographical Writings, ed. Peter Demetz (USA: Random House, 1995), p. 312.

$43 \mathrm{lbid}$.
} 
The way Hobbes negotiates an a-teleological eschatology is by making a very explicit distinction between goal and end. His more general break with teleological thought is underlined in his commentary on Thomas White when he says that "goal" taken as "objective" and "intention" does not mean the same as when it is taken as "final point" or the "terminus ad quem of the motion'". ${ }^{44}$ By distinguishing between goal and end in this way, Hobbes simultaneously allows for motion that is ateleological, but also a conception of time and history which contains an eschaton. Hobbes is unusual in this regard given that eschatology is more commonly associated with a teleological view of history. As Jacob Taubes writes:

The nature of time is summed up by its irreversible unidrectionality [Einsinnigkeit]. From a geometrical point of view, time runs in a straight line in one direction [einsinnig]. The direction of this straight line is irreversible. This unidirectionality is common both to life and time. Unidirectionality and irreversibility are fundamental to their meaning. The purpose of this unidrectionality lies in the direction itself. The direction is toward an end; otherwise it would be directionless. The end is essentially Eschaton. ${ }^{45}$

What we find in Hobbes, however is an a-teleological eschatology. Rather than progression occurring as a result of the end - as Aristotle would have it - or as the outcome of various stages of history which progress toward the final end - as Hegel would have it - Hobbes presents the Eschaton as something autonomous, bound to occur, not because of progress, but because of a promise by God. ${ }^{46}$ The structure of the promise is such that whatever actions humans take, the covenant with God cannot be broken and thus the kingdom to come, as what is promised, will occur. It is thus not the case that the Leviathan defers the end of time, nor does terrestrial sovereignty produce time, but rather, it occurs in a space between two kingdoms that is not of time. This goes directly against the tradition of eschatology which Jacob Taubes reads as operating in Hegel's philosophy in which the "goal of history is the kingdom of the spirit". 47

\footnotetext{
${ }^{44}$ Hobbes, De Mundo Examined, p. 493.

45 Jacob Taubes, Occidental Eschatology, trans. David Ratmoko (Stanford University Press, 2009), pp. 3-4.

${ }_{46}$ Martel, Subverting, p. 137.

47 Taubes, Occidental, p. 93.
} 
The state's goal which is characterized by Hobbes as safety, is also a concern with happiness, as he writes in De Cive: 'by 'safety' we should understand not only the "simple preservation of life (but to the extent that is possible) that of a happy life". ${ }^{48}$ Happiness and safety are, we argue, not to be read as the telos of the state which determines its movement, but rather its goal. If the raison d'être of the state is evacuated from teleology, what is left is a goal for the state (happiness and safety) but one that cannot - in the form of the Leviathan - reach fulfillment. As Agamben has noted in Paul's first letter to the Thessalonians (which Hobbes cites in chapter 44 of Leviathan) "peace and security coincide with the catastrophic advent of the day of the Lord ('When they say, "there is peace and security", then destruction will come upon them". ${ }^{49}$ In this sense the state cannot reach a state of fulfillment as such, because as soon as it does the eschaton emerges.

One of the consequences of the evacuation of eschatology from Leviathan is the notion that it is the Leviathan which produces time, and that this time is eternal. This claim is reinforced by Horst Bredekamp for whom Hobbes's claim that "this is the Generation of that great Leviathan, or rather (to speak more reverently) of that mortall God to which we owe under the Immortal God, our peace and defence"50 should be read in the understanding that by generation Hobbes means "the creation not only of a body but also of time'". ${ }^{51}$ It is this reading, the reading of Leviathan as creator of time that leads to the view that the time of the Leviathan is artificial eternity: "the Leviathan is built to last". ${ }^{52}$ What we argue here, however, is that this account emphasises the eternal aspect at the expense of its artificiality. The eternity that Hobbes here refers to is an artificial one. Concrete eternity only occurs with the advent of the Eschaton where the "temporal end is eternity". ${ }^{53}$ To claim, then, that the Leviathan is built to last is a mistake, one that covers over the ways in which the Leviathan is manifestly not built to last, i.e. in its mortal nature, where it will necessarily disappear once the sovereignty of God is re-established. It is this fragile

\footnotetext{
48 Hobbes, Citizen, p. 143.

49 Agamben, Stasis, p. 53.

50 Hobbes, Leviathan, p. 134.

51 Bredekamp, Hause and Bond "Walter Benjamin to Carl Schmitt," p. 255.

52 lbid., p. 258.

53 Taubes, Occidental, p. 4.
} 
finite aspect to sovereignty that we would stress here, the Leviathan is not a God, but a mortal thing that cannot last.

\section{An eschatological reading of sovereignty}

The ambivalent structure of the katechon - which resides for Esposito in the fact that by being entrusted with the function of protection from chaos, it simultaneously defers the second coming of Christ -, resonates with Paulo Virno's understanding of the katechon. For Virno too, the katechon not only oscillates between the negative and the positive but it also preserves the very oscillation between the two: "by placing itself in opposition to danger and also to the elimination of that danger, to the Antichrist and also to the Messiah, the katechon delays the end of the world." 54 It is in this sense that, for Virno, the katechon is "a radically anti-eschatological" concept". ${ }^{55}$ Reading Hobbes's theory of the state from a Schmittian katechontic perspective, therefore, amounts to a straightforward rejection of the a-teleological eschatology at work in Hobbes's philosophical system. At the center of both interpretations of Hobbes's theory of the state - the katechontic interpretation as put forward by Schmitt and the eschatological one, as discussed in the previous section - lies the question of the theological foundation of sovereignty and the problem of secularization.

In section two of the Sovereign and the Beast Derrida approaches the question of sovereignty in Hobbes's Leviathan by interrogating the sharp division established by Hobbes between the obligations owed to God and those owed to the state. For Hobbes, as Derrida suggests, sovereignty is absolutely indivisible, and hence, there can be no higher authority, no higher power than the sovereign. Those claiming that the obligations owed to God are to be prioritized over and above those owed to the sovereign are, according to Hobbes, misguided: "but this pretence of Covenant with God, is so evident a lye, even in the pretenders own consciences, that it is not only an act of an unjust, but also of a vile, and unmanly disposition."56 There is, according to Hobbes, no "Covenant with God, but by mediation of some body that

\footnotetext{
54 Paolo Virno, Multitude between Innovation and Negation (New York: Semiotext(e), 2008), 60.

55 lbid.

56 Hobbes, Leviathan, p.137.
} 
representeth Gods Person." 57 Derrida takes this image of the sovereign as a mediator, as a lieutenant, to leave open "the possibility of a Christian foundation of politics". ${ }^{88}$ But yet, what is at stake, as Derrida himself has put it, is "nothing less than the foundation - theological or not, religious or not, Christian or not - of the concept of political sovereignty" ${ }^{59}$

For Derrida, although Hobbes "does all he can to anthropologize and humanize the origin and foundation of state sovereignty", 60 this anthropologization remains attached to theology by a "double umbilical cord": On the one hand, the human creation of the state imitates the work of God, and, on the other, sovereign power represents and stands in the place of God. This means, for Derrida, that one cannot simply claim that the modern concept sovereignty is emancipated from theology as it "retains a profound and fundamental theological and religious basis". ${ }^{61}$ Nevertheless, as we have claimed earlier, Derrida's insistence on the theological overtone of Hobbes's theory of sovereignty, although implicitly at odds with the thesis that Hobbes's Leviathan is a secularized katechon, does not capture the eschatological underpinnings of sovereignty, thereby arriving at partial conclusions regarding the relation between the kingdom of God and the kingdom of the Leviathan. In short, the double umbilical cord that for Derrida ties Hobbes's theory of sovereignty to the theological realm has an eschatological nature.

The evacuation of concrete eschatology from Hobbes's Leviathan, which is premised on the Schmittian-katechontic reading of Hobbes, comfortably places Hobbes's political philosophy within a liberal understanding of sovereignty "premised on the abandonment of eschatology and the renunciation of immediate expectations of redemption." 62 Indeed, with the deactivation of eschatology, the katechon allows for an infinite government that "extends its blind and derisive dominion to every aspect of social life." 63 From this katechontic, yet mistaken reading, Hobbes's theory of the state finds corroboration in contemporary forms of government which, for Agamben

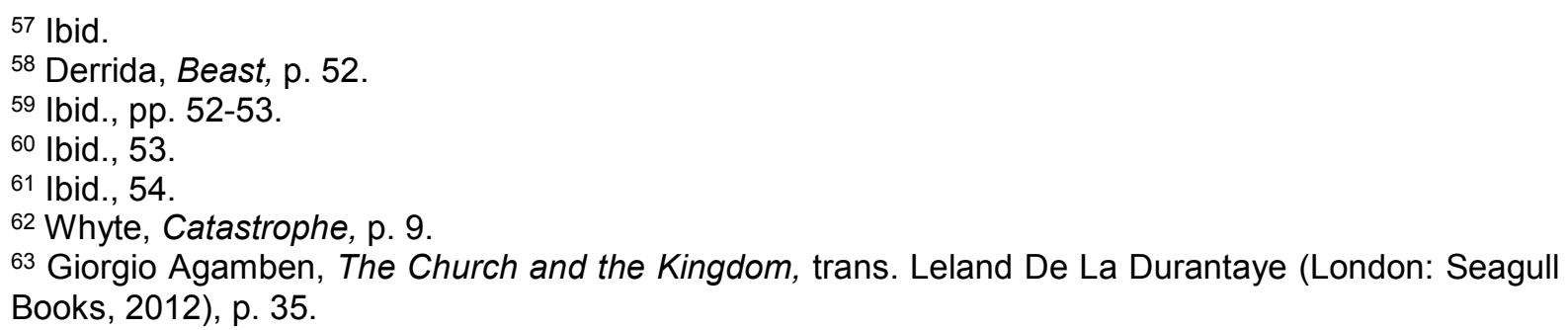


take the form of an uninterrupted biopolitical economy that continuously defer the last Judgment. Crucially, for Agamben, "according to Christian theology there is only one legal institution which knows neither interruption nor end: hell. The model of contemporary politics - which pretends to an infinite economy of the world - is thus truly infernal." 64

At first glance, a paradox therefore appears underneath the eschatological articulation between the kingdom of the Leviathan and the kingdom of God in Hobbes's thought. If the biopolitical economy that characterises the form that government takes under liberalism is grounded on a katechontic understanding of sovereignty, which in turn requires a rejection of eschatology, how should we then conceive of the biopolitical function of security in Hobbes's political thought, which as we seen, is saturated with eschatology? What is to be made of Agamben's claim that the frontispiece to the Leviathan "is also a courier that announces the biopolitical turn that sovereign power was preparing to make" ${ }^{\prime 65}$ once Hobbes's theory of the state is placed in is eschatological locus? To put it shortly: how is it possible that we have, in Hobbes, a biopolitical turn that far from being predicated on the secularization of the Katechon coincides with an eschatological motif?

This "biopolitical turn" becomes intelligible in the frontispiece of the Leviathan. Here there is a depiction of an almost empty city, devoid of people (who are in fact found in the body of the sovereign which dwells outside of the city). There are, however, some barely visible figures if one looks closely. Agamben credits Francesca Falk with establishing "that the two figures standing near the cathedral are wearing the characteristic beaked mask of plague doctors." 66 The other figures are armed guards:

like the mass of plague victims, the unrepresentable multitude can be represented only through the guards who monitor its obedience and the doctors who treat it. It dwells in the city, but only as the object of the duties and concerns of those who exercise sovereignty. ${ }^{67}$

\footnotetext{
$64 \mathrm{lbid}$.

${ }^{65}$ Agamben, Stasis, p. 38.

66 lbid., p. 37.

67 Ibid., p.38.
} 
In placing the doctors and guards together as those who are "exercising sovereignty," the way in which security and health became conjoined in a political relation is here given expression. Health and security were the concerns of a sovereign who, as discussed previously, had its raison d'être summed up by Hobbes as safety, which is always already a concern with happiness. ${ }^{68}$ It is worth noting, however, that Foucault's biopolitical theory puts Hobbes's theory of sovereignty at odds with biopolitics all together. Indeed, in Society Must be Defended Foucault uses Hobbes's theory of sovereignty in order to make an analytical and a historical distinction between sovereignty and biopolitics. Here, although Foucault holds that we cannot simply locate a substitution of sovereignty by biopolitics, he understands biopolitics as emerging in a moment at which sovereignty retreats into the shadows: "an important phenomenon occurred in the seventeenth and eighteenth centuries: the appearance - one should say the invention - of a new mechanism of power which had very specific procedures, completely new instruments, and very different equipment. It was, I believe, absolutely incompatible with relations of sovereignty". ${ }^{69}$ This supposed absolute incompatibility allows Foucault to define biopolitics as a "type of power [that] is the exact, point-for-point opposite of the mechanics of power that the theory of sovereignty described."70 The sovereign right to take life - the right of killing - is replaced by a power to foster life or disallow it to the point of death; the administration of bodies and the calculated management of life is then what becomes the centre of political strategies, as opposed to the right over life and death of sovereign power. ${ }^{71}$ In short, biopolitics for Foucault, as Esposito has put it, is "primarily that which is not sovereignty."72

\footnotetext{
${ }^{68}$ Although for Agamben, Western politics "is a biopolitics from the very beginning" he considers that the politicisation of bare life constitutes the "decisive event of modernity and signals a radical transformation of the political-philosophical categories of classical thought". From this perspective, the claim that Hobbes's theory of sovereignty announces a biopolitical turn would find corroboration here. (Giorgio Agamben, Homo Sacer: Sovereign Power and Bare Life. Trans. Daniel Heller-Roazen. [California: Stanford University Press]) p. 181, p.4.

69 Michell Foucault, "Society Must be Defended": Lectures at the Collège de France, 1975-1976, ed. M. Bertani \& A. Fontana. (New York: Picador, 2003), p. 35.

70 lbid., 36.

${ }^{71}$ Michell Foucault, The History of Sexuality: Volume 1: An Introduction. (New York: Pantheon Books, 1978), p. 140.

72 Roberto Esposito, Bíos: Biopolitics and Philosophy. (Minneapolis, MN: University of Minnesota Press, 2008), p. 33.
} 
Nevertheless, as we have seen, Hobbes's theory of sovereignty, far from being exhausted in the right to kill, is characterized primarily by functions that foresee the very mechanisms of power that Foucault describes as biopolitical, functions that testify to the crucial role of both the figure of the guard and the doctor in the frontispiece. For instance, in chapter XXIV of Leviathan Hobbes makes explicit that "The nutrition of a commonwealth consisteth, in the plenty, and distribution of materials conducing to life,"73 and then again in chapter XXX he specifies that by safety he does not mean "a bare preservation, but also all other contentments of life, which every man by lawful industry, without danger, or hurt to the commonwealth, shall acquire to himself." 74 Even more exemplary of the biopolitical nature of his theory of sovereignty, in talking about the functions of the commonwealth in De Cive, Hobbes suggests that if "a woman gives birth to a deformed figure, and the law forbids killing a human being, the question arises whether the newborn is a human being. The question then is, what is a human being? No one doubts that the commonwealth will decide."75

It is also in Agamben, however, that we find an explicit link between biopolitics and the Katechon: "it is the katechon that ensures the perpetuation of a catastrophic form of government that oscillates between the biopolitical protection and the abandonment of life". ${ }^{76}$ Liberal government can be understood as katechontic precisely in the sense that it gives the impression of deferring the ultimate crisis: bloodshed and disorder that would reign in its absence. Agamben has treated the katechon thus writing that its force is called "law or state dedicated as it is to economy, which is to say dedicated as it is to the indefinite - and indeed infinie governance of the world". ${ }^{77}$ It is this Schmittian interpretation of the katechon that allows government to appear (and here we find the familiar reading of Hobbes) as a bulwark against catastrophe. What has happened, we argue, is that a form of liberal government has been retroactively read into Hobbes that doesn't appear in Hobbes (at least in this form), himself. What our reading provides is thus a corrective to those

\footnotetext{
${ }^{73}$ Hobbes, Leviathan, p. 190.

74 Ibid., p.255.

${ }^{75}$ Hobbes, Citizen, p. 215.

${ }^{76}$ Whyte, Catastrophe, p. 9.

77 Giorgio Agamben, The Church and the Kingdom, trans. Leland De La Durantaye (London: Seagull Books, 2012), p. 35.
} 
interpretations that read Hobbes as founding a certain form of liberal government that is katechontic, deferring the final crisis, yet oscillating from crisis to crisis in a perpetual state of emergency.

By removing an essential telos for the state (for as discussed previously the motion of the state is necessarily a-teleological) its reason for being takes on a different hue to that of the liberal paradigm of government. Indeed, the liberal form that sees security as the telos, and end-point, an end in itself, then the catastrophe of incessant biopolitical governance is rendered inescapable. There is no way out of the state, for it is the state which provides life (or, indeed the conditions which mean life is possible). The state in this view then comes to occupy the entire horizon of political life, with a collapse into (an apolitical state of) chaos and disorder being seen as the only alternative. In this sense the state is the only thing that stands between life that can be lived and a state of war which renders life unliveable.

What is at stake is whether we align politics with the prevention of the dissolution of the current order of things or with something altogether different, as opening a horizon of the end of the current order of things, its dissolution which gives to us a form of hope. This is not, however to relegate this hope to some form of post-history or indeterminate future, but rather to say that the future, as James Martel has put it, is radically contingent, and does not consist in the infinite deferral of chaos and catastrophe. ${ }^{78}$

\section{Messianism, eschatology and politics}

As we have seen, Hobbes's eschatology has a particular a-teleological character. Certainly, Hobbes's predicament does not focus on the "yet to come" but, as Martel has put it, "on the time of the now (including our " kingdomless" time)". ${ }^{79}$ Here, once again, the similarity between Hobbes and Benjamin comes to the fore. Just as for Benjamin, "every second of time was the strait gate through which the Messiah might

78 Martel, Subverting, 215.

79 Ibid. 
enter,"80 so does, according to Hobbes's eschatology, the future become, as it were, always already here:

Rather than becoming 'homogenous empty time' a sovereign future of life everlasting (i.e. eternal antipolitical, the very nightmare of a nonfuture that Arendt resists in her own work), the future becomes a matter of human responsibility and possibility. Stripped of its magical illusions, the future does not become empty but rather a blank reflection of something as yet unmade and unknown, something we strive toward via our promises. ${ }^{81}$

In this sense, Hobbes's eschatology comes close to Paul's conception of the messianic event as "the time of the now". Agamben, who stresses the distinction between eschatology as the end of time, and messianic time as a "time that remains between time and its end" 82 fails to grasp the specificity of Hobbes's eschatology. Indeed, from the perspective of this distinction, Hobbes's eschatology is not situated on the side of prophecy - that is, the future referential that announces the coming of the Messiah - but neither does it completely coincide with Agamben's notion of the messianic time as time of the end. Rather, Hobbes's eschatology, by virtue of its non-teleological nature, sits perfectly between prophecy and messianism: just as in Benjamin's thought "where messianic time is not chronologically distinct from historical time" 83 so does, in Hobbes's thought, the historical time of faith and prophecy coincide chronologically with the a-historical time of the Leviathan. In this particular sense, one of the paradoxes of the messianic kingdom that Agamben identifies in Potentialities, could also be found in Hobbes's articulation of the eschatological time and the time of the profane kingdom:

One of the paradoxes of the messianic kingdom is, indeed, that another world and another time must make themselves present in this world and time. This means that historical time cannot simply be canceled and that messianic time, moreover, cannot be perfectly homogenous with history: (the two times must instead accompany each other according to modalities that cannot be reduced to a dual logic (this world/the other world). ${ }^{84}$

\footnotetext{
80 Walter Benjamin, "Thesis on the Philosophy of History" in Illuminations trans. by Harry Zohn and Ed. by Hannah Arendt (New York: Schocken Books, 1968), p. 263.

81 Martel, Subverting, p. 217.

${ }^{82}$ Agamben, Time, p. 62.

83 Giorgio Agamben, Potentialities: Collected Essays in Philosophy, ed. and trans. Daniel HellerRoazen (Stanford University Press, 1999), p. 168.

84 Ibid
} 
It is only in this context that Hobbes's theory of sovereignty acquires its proper meaning. Indeed, we are now in a position to claim that the bond that ties Benjamin's thought to that of Hobbes go much further than the "curious affinity" between them as observed by Agamben - allows us to infer. Certainly, it is not only the case that neither for Hobbes nor for Benjamin does the profane realm of politics have a katechontic function. Also, and more importantly, from the perspective of the eschatological underpinnings of Hobbes's theory of the State, "in a very real sense, the future is already partially here via our promises and convents as instantiations of God's promise". ${ }^{85}$ Just as in Benjamin's messianism in which the "Day of Judgment is not different from any others" 86 and Agamben's reading of Paul according to which messianic time is neither "to come" nor the end of time, so does Hobbes's eschatology coincides with "the time of the now." 87

It is in this light that one should read Pocock's claim that Hobbes's politics "have taken on a messianic dimension, just as the messianism they entail is almost brutally political." 88 This political brutality cuts the knot that ties liberalism with what Agamben has identified as the petrified or paralysed messianism that "like all messianism, nullifies the law, but then maintains it as the Nothing of Revelation in a perpetual and indeterminable state of exception". ${ }^{89}$ Indeed, Hobbes's eschatology forces us to divorce this theory of the state from all nihilistic considerations of the realm of profane politics, coinciding with accounts of the messianic event as a crisis and a "radical transformation of the entire order of the law". ${ }^{90}$ This implies a subversion of Leviathan similar to that of James Martel for whom Hobbes "affords us a precious glimpse into a non-sovereign politics, one that, even if it fails to overcome sovereignty once and for all, does suggest that sovereignty is neither inevitable nor necessary the 'best' of a set of bad political choices". ${ }^{91}$ Furthermore, as we have seen, placing Hobbes's notion of sovereignty within the eschatological coordinates of his thought necessarily entails a displacement of the katechontic reading of the State in itself and of its biopolitical function of peace and security. To put it

\footnotetext{
${ }^{85}$ Martel, Subverting, p. 215.

${ }^{86}$ Agamben, Potentialities, p. 160.

${ }^{87}$ Agamben, Time, p.62.

${ }^{88}$ Pocock, Time, History and Eschatology, pp. 173-174.

89 Agamben, Potentialities, p. 171.

90 Ibid., p. 163.

${ }^{91}$ Martel, Subverting, p. 245.
} 
differently, in Hobbes, this katechontic biopolitical paradigm is turned on its head. Peace and security are not the telos of the state but it's end. Thus biopolitics cannot take the form of an eternal oscillation but must activate the time of the end. This radically undermines any sense in which the Leviathan state is a barrier between peace and war, chaos and order by deferring catastrophe. By highlighting the place of God within Hobbes's work we can begin to rethink the very foundations upon which liberal government has been thought. 